\title{
Antioxidant activity of rice plants sprayed with herbicides ${ }^{1}$
}

\author{
Marcos André Nohatto ${ }^{2}$, Dirceu Agostinetto ${ }^{2}$, \\ Ana Claudia Langaro ${ }^{2}$, Claudia de Oliveira ${ }^{2}$, Queli Ruchel ${ }^{2}$
}

\section{ABSTRACT}

Understanding the physiological defense behavior of plants subjected to herbicide application may help to identify products with higher or lower capacity to cause oxidative stress in crops. This study aimed at evaluating the effect of herbicides in the antioxidant activity of rice plants. The experimental design was completely randomized, with six replications. Treatments consisted of the herbicides bentazon (photosystem II inhibitor; $960 \mathrm{~g} \mathrm{ha}^{-1}$ ), penoxsulam (acetolactate synthase inhibitor; $60 \mathrm{~g} \mathrm{ha}^{-1}$ ), cyhalofop-butyl (acetyl coenzyme-A carboxylase inhibitor; $315 \mathrm{~g} \mathrm{ha}^{-1}$ ) and a control. After the herbicides application, samples of rice shoots were collected at 12, 24, 48 and 96 hours after application (HAA). The components evaluated were hydrogen peroxide $\left(\mathrm{H}_{2} \mathrm{O}_{2}\right)$, lipid peroxidation and activity of the antioxidant enzymes superoxide dismutase (SOD) and catalase (CAT). Bentazon (up to 24 HAA) and penoxsulam (48 and 96 HAA) reduced the CAT activity. Moreover, these herbicides increased the levels of $\mathrm{H}_{2} \mathrm{O}_{2}$, lipid peroxidation and SOD activity, indicating a condition of oxidative stress in rice plants. The cyhalofop-butyl herbicide did not alter the antioxidant activity, showing that it causes less stress to the crop.

KEY-WORDS: Oryza sativa; oxidative stress; phytotoxicity.

\section{INTRODUCTION}

The selectivity of herbicides depends on several factors, such as ingredients features, plants, application method and environmental conditions, as well as absorption, metabolism or translocation of herbicides (Hess 2000). Even if a particular active ingredient is classified as selective to plants, the energy expenditure for detoxification of xenobiotics may cause phytotoxicity problems, damaging the growth and development of crops (Song et al. 2007).

\section{RESUMO}

Atividade antioxidante de plantas de arroz pulverizadas com herbicidas

O entendimento do comportamento fisiológico de defesa de plantas submetidas à aplicação de herbicidas auxilia na identificação de produtos com maior ou menor capacidade de causar estresse oxidativo na cultura. Objetivou-se avaliar o efeito de herbicidas na atividade antioxidante de plantas de arroz. O delineamento experimental utilizado foi o completamente casualizado, com seis repetições. Os tratamentos constituíram-se dos herbicidas bentazona (inibidor de fotossistema II; $960 \mathrm{~g} \mathrm{ha}^{-1}$ ), penoxsulam (inibidor de acetolactato sintase; $60 \mathrm{~g} \mathrm{ha}^{-1}$ ), cialofope-butílico (inibidor de acetilcoenzima A carboxilase; $315 \mathrm{~g} \mathrm{ha}^{-1}$ ) e testemunha sem aplicação. Após aplicação dos herbicidas, foram realizadas coletas da parte aérea do arroz às 12, 24, 48 e 96 horas após a aplicação (HAA). As variáveis avaliadas foram peróxido de hidrogênio $\left(\mathrm{H}_{2} \mathrm{O}_{2}\right)$, peroxidação lipídica e atividade das enzimas antioxidantes superóxido dismutase (SOD) e catalase (CAT). Bentazona (até 24 HAA) e penoxsulam (48 e 96 HAA) reduziram a atividade da CAT. Além disso, esses herbicidas aumentaram o nível de $\mathrm{H}_{2} \mathrm{O}_{2}$, peroxidação lipídica e atividade da SOD, indicando condição de estresse oxidativo nas plantas de arroz. O herbicida cialofope-butílico não alterou a atividade antioxidante, sinalizando menor capacidade de causar estresse à cultura.

PALAVRAS-CHAVE: Oryza sativa; estresse oxidativo; fitotoxicidade.

Phytotoxicity caused by the use of herbicide chemical control happens mainly due to the increase of reactive oxygen species (ROS). These molecules are highly reactive to lipids of cell membranes, causing lipid peroxidation and, consequently, the formation of radicals, irreversibly damaging cell membranes (Fleck \& Vidal 2001). The direct response of cell membrane damage by lipid peroxidation is leakage of cellular contents, disrupting several physiological processes of plants, such as photosynthesis and defense mechanisms (Kruse et al. 2006).

1. Manuscript received in Oct./2015 and accepted for publication in Feb./2016 (http://dx.doi.org/10.1590/1983-40632016v4638011).

2. Universidade Federal de Pelotas, Faculdade de Agronomia Eliseu Maciel, Departamento de Fitossanidade, Pelotas, RS, Brasil. E-mails: marcosnohatto@hotmail.com, agostinetto.d@gmail.com,namelia.langaro@gmail.com,oliveirac.agro@gmail.com, queli.ruchel@yahoo.com.br. 
To mitigate the oxidative damage caused by ROS, plants have a defense system composed of antioxidant enzymes, such as superoxide dismutase (SOD), catalase (CAT), ascorbate peroxidase (APX) and glutathione reductase (GR) (Gill \& Tuteja 2010). Understanding this defense system and the physiological response of plants to herbicide stress may facilitate the investigation on phytotoxicity.

Bentazon, penoxsulam and cyhalofopbutyl are herbicides intensively used in rice crop. Bentazon inhibits photosynthesis by binding to the quinone-binding $(\mathrm{QB})$ niche on the $\mathrm{D} 1$ protein of the photosystem II complex, localized in the chloroplast thylakoid membranes. Herbicide binding at this protein location blocks the electron transport from $\mathrm{Q}_{\mathrm{A}}$ to $Q_{B}$ and stops $\mathrm{CO}_{2}$ fixation and production of ATP and $\mathrm{NADPH}_{2}$, which are essential for plant growth (Han \& Wang 2002).

Penoxsulam acts as an acetolactate synthase (ALS) inhibitor, which interferes with synthesis of the amino acids valine, leucine and isoleucine (Senseman 2007). These amino acids are necessary for protein synthesis and, therefore, are essential for cell metabolism. Thus, the herbicide will disrupt cell division, consequently stopping the plant growth (Oliveira Júnior et al. 2011).

Cyhalofop-butyl acts by inhibiting acetylcoenzyme A carboxylase, reducing the ability of plants to produce malonyl-coenzyme $\mathrm{A}$, which is needed for the synthesis of fatty acids (Ruiz-Santaella et al. 2006). Fatty acids are essential constituents of plasma membranes of cells and organelles. Deficiency of fatty acids causes disorders of cell permeability and breaks in the structure of cell membranes (Oliveira Júnior et al. 2011).

Although recommended for rice, there are field reports of phytotoxicity in the crop after the application of bentazon, penoxsulam and cyhalofopbutyl, which drive the investigation on the capacity of these products to cause oxidative stress in the crop. Thus, this study aimed at evaluating the effect of these herbicides on the antioxidant activity of rice plants.

\section{MATERIAL AND METHODS}

The experiment was conducted in a greenhouse at the Universidade Federal de Pelotas, in Capão do Leão, Rio Grande do Sul State, Brazil, during the 2011/2012 cropping season.
Plastic pots $(8 \mathrm{~L})$ filled with Yellow-Red Alfissol were used. The experimental design was completely randomized, with six replications. The herbicides tested were: bentazon $480 \mathrm{~g} \mathrm{~L}^{-1}\left(960 \mathrm{~g} \mathrm{ha}^{-1}\right)$, penoxsulam $240 \mathrm{~g} \mathrm{~L}^{-1}\left(60 \mathrm{~g} \mathrm{ha}^{-1}\right)$, cyhalofop-butyl $180 \mathrm{~g} \mathrm{~L}^{-1}\left(315 \mathrm{~g} \mathrm{ha}^{-1}\right)$ and a control. The herbicide solution was applied with specific adjuvants, such as mineral oil to bentazon $\left(1,000 \mathrm{~mL} \mathrm{ha}^{-1}\right)$ and cyhalofop-butyl $\left(3,000 \mathrm{~mL} \mathrm{ha}^{-1}\right)$ and vegetable oil to penoxsulam $\left(1,000 \mathrm{~mL} \mathrm{ha}^{-1}\right)$. The herbicide rates were established considering the highest recommended dose for rice (Agrofit 2014). Each experimental unit consisted of 16 plants (IRGA 424 cultivar), in order to obtain enough plant biomass for laboratorial analyses. Spraying was performed at 15 days after crop emergence (DAE), using a pressurized $\mathrm{CO}_{2}$ backpack sprayer equipped with 110.02 points range, with a flow rate of $150 \mathrm{~L} \mathrm{ha}^{-1}$. Flood irrigation began one day after the herbicide application.

For the rice shoots experiment, samples were taken at 12, 24, 48 and 96 hours after application (HAA) and stored at $-80^{\circ} \mathrm{C}$, until the evaluation of hydrogen peroxide $\left(\mathrm{H}_{2} \mathrm{O}_{2}\right)$; lipid peroxidation, in terms of thiobarbituric acid reactive species (TBARS); and activity of the antioxidant enzymes superoxide dismutase (SOD) and catalase (CAT). The collection time was based on preliminary tests, considering the mode of action of the herbicides used in the study.

Cell damage in tissues was determined by the hydrogen peroxide $\left(\mathrm{H}_{2} \mathrm{O}_{2}\right)$ content (Sergier et al. 1997) and thiobarbituric acid reactive species (TBARS) via accumulation of malondialdehyde (MDA) (Heath \& Packer 1968). To perform these analysis, $0.2 \mathrm{~g}$ of leaf tissue were grinded in liquid nitrogen, homogenized in $2 \mathrm{~mL}$ of trichloroacetic acid $0.1 \%(\mathrm{w} / \mathrm{v})$ and centrifuged at $14,000 \mathrm{rpm}$, for $20 \mathrm{~min}$. To quantify $\mathrm{H}_{2} \mathrm{O}_{2}, 0.2 \mathrm{~mL}$ of the supernatant were added to $0.8 \mathrm{~mL}$ of $10 \mathrm{mM}$ phosphate buffer ( $\mathrm{pH} 7.0)$ and $1 \mathrm{~mL}$ of $1 \mathrm{M}$ potassium iodide. The solution was kept for $10 \mathrm{~min}$ at room temperature, and absorbance read at $390 \mathrm{~nm}$. The $\mathrm{H}_{2} \mathrm{O}_{2}$ concentration was determined using the standard curve and expressed in milimol per gram of fresh weight ( $\left.\mathrm{mM} \mathrm{g}^{-1} \mathrm{FW}\right)$.

To determine TBARS, $0.5 \mathrm{~mL}$ aliquots from the supernatant described above were added to $1.5 \mathrm{~mL}$ of thiobarbituric acid (TBA) $0.5 \%(\mathrm{w} / \mathrm{v})$ and trichloroacetic acid $10 \%(\mathrm{w} / \mathrm{v})$ and incubated at $90{ }^{\circ} \mathrm{C}$, for $20 \mathrm{~min}$. The reaction was stopped on ice, for $10 \mathrm{~min}$. The absorbance was read at $532 \mathrm{~nm}$, discounting the non-specific absorbance at $600 \mathrm{~nm}$. 
The concentration of MDA was calculated using the absorptivity coefficient of $155 \mathrm{mM} \mathrm{cm}^{-1}$, and the results were expressed in $\mathrm{nM} \mathrm{MDA} \mathrm{g}^{-1} \mathrm{FW}$.

To determine the activity of the antioxidant enzymes SOD and CAT, a first extraction was carried out, with $0.2 \mathrm{~g}$ of leaf samples grinded in a porcelain mortar, in the presence of liquid nitrogen and $0.02 \mathrm{~g}$ of polyvinylpyrrolidone (PVP). Then, the following solutions were added to the grinded tissue: $900 \mu \mathrm{L}$ of $200 \mathrm{mM}$ phosphate buffer ( $\mathrm{pH} 7.8$ ), $18 \mu \mathrm{L}$ of $10 \mathrm{mM}$ EDTA, $180 \mu \mathrm{L}$ of $200 \mathrm{mM}$ ascorbic acid and $702 \mu \mathrm{L}$ of ultrapure water. The mixed solution was centrifuged at $14,000 \mathrm{rpm}$, at $4{ }^{\circ} \mathrm{C}$, for $20 \mathrm{~min}$. From this extract, protein samples were quantified using the Bradford (1976) method, by adding $60 \mu \mathrm{L}$ of extract to $2 \mathrm{~mL}$ of Bradford solution and performing the absorbance reading at $595 \mathrm{~nm}$ wavelength. The standard curve was estimated with globulin and results were expressed in milligrams of protein (mg protein) by FW.

The SOD activity was determined according to a method adapted from Peixoto (1999). Using this method, the inhibition of the reduction of nitro blue tetrazolium (NBT) by the enzyme extract was determined, avoiding, therefore, the formation of chromophore. In this assay, one unit of enzyme activity (AU) of SOD was regarded as the amount of enzyme required to reach $50 \%$ inhibition of NBT reduction by the SOD contained in the enzyme extract. For the reaction, the following components were added to a test tube: $1 \mathrm{~mL}$ of potassium phosphate buffer at $100 \mathrm{mM}(\mathrm{pH} 7.8), 400 \mu \mathrm{L}$ of $70 \mathrm{mM}$ methionine, $20 \mu \mathrm{L}$ of $10 \mathrm{mM}$ EDTA, $390 \mu \mathrm{L}$ of ultrapure water, $150 \mu \mathrm{L}$ of $1 \mathrm{mM} \mathrm{NBT}, 20 \mu \mathrm{L}$ of $0.2 \mathrm{mM}$ riboflavine and $20 \mu \mathrm{L}$ of the extract. Then, the tubes were exposed to a $15 \mathrm{~W}$ bright fluorescent lamp chamber, for $10 \mathrm{~min}$, and the $560 \mathrm{~nm}$ absorbance was recorded. Tubes without extract, exposed and not exposed to light, were considered as blanks in the reaction. The activity was determined by calculating the amount of extract that inhibited $50 \%$ of the NBT reaction and expressed in $\mathrm{AU} \mathrm{mg}{ }^{-1}$ protein $\mathrm{min}^{-1}$.

The CAT activity was determined by recording the consumption of $\mathrm{H}_{2} \mathrm{O}_{2}$ (extinction coefficient of $\left.39.4 \mathrm{mM} \mathrm{cm}^{-1}\right)$. The reaction mixture contained $1 \mathrm{~mL}$ of potassium phosphate buffer at $200 \mathrm{mM}(\mathrm{pH} 7.0)$, $850 \mu \mathrm{L}$ of ultrapure water, $100 \mu \mathrm{L}$ of hydrogen peroxide at $250 \mathrm{mM}$ and $50 \mu \mathrm{L}$ of the extract. The absorbance at a wavelength of $240 \mathrm{~nm}$ was recorded in a spectrophotometer (Ultrospec 6300 Pro UV/ Visible - Amersham Bioscience), for 90 seconds, with readings at intervals of 7 seconds (Sudhakar et al. 2001). For both enzymes (SOD and CAT), it was considered that the decrease of one unit of absorbance was equivalent to one active unit (AU) of enzyme. The activity of the total extract was determined from the amount of extract that reduced the absorbance reading in one $\mathrm{AU}$, being expressed in $\mathrm{AU} \mathrm{mg}^{-1}$ protein $\min ^{-1}$.

Data were analyzed for normality (ShapiroWilk) and subsequently subjected to analysis of variance $(p<0.05)$. In case of significance, the treatment means were compared within each evaluation by the Tukey test $(\mathrm{p}<0.05)$.

\section{RESULTS AND DISCUSSION}

For $\mathrm{H}_{2} \mathrm{O}_{2}$, it was found that, for the evaluations performed at 24, 48 and 96 HAA, there were no differences between the herbicide treatments, when compared to the control (Figure 1). On the other hand, at $12 \mathrm{HAA}$, higher $\mathrm{H}_{2} \mathrm{O}_{2}$ values were observed after the application of bentazon, as compared to the control and other herbicides (Figure 1), indicating that the use of the herbicide initially caused an increase in the production of reactive oxygen species.

Oxidative stress caused by increased concentration of reactive oxygen species can activate

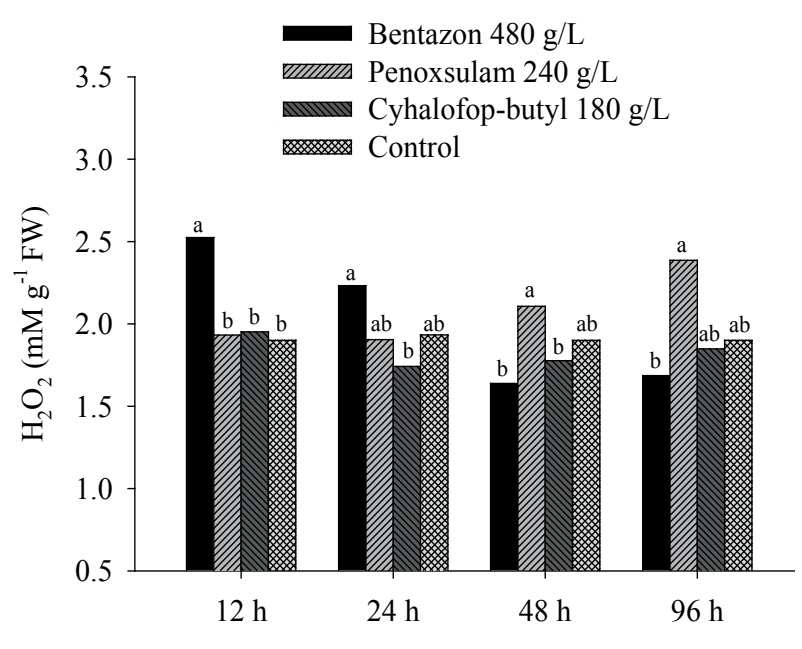

Figure 1. Content of hydrogen peroxide $\left(\mathrm{H}_{2} \mathrm{O}_{2}\right)$ of rice plants in response to the use of bentazon (960 $\left.\mathrm{g} \mathrm{ha}^{-1}\right)$, penoxsulam $\left(60 \mathrm{~g} \mathrm{ha}^{-1}\right)$, cyhalofop-butyl $\left(315 \mathrm{~g} \mathrm{ha}^{-1}\right)$ and control, at 12, 24, 48 and 96 hours after application (Capão do Leão, Rio Grande do Sul State, Brazil, 2011/2012). Means followed by the same letter on the bars do not differ within each evaluation time by the Tukey test $(\mathrm{p}<0.05)$. 
the programmed cell death due to membrane lipid peroxidation, protein oxidation, enzyme inhibition and damage to DNA and RNA (Ma et al. 2013). However, in later evaluations (24, 48 and 96 HAA), bentazon did not differ from the control, in terms of $\mathrm{H}_{2} \mathrm{O}_{2}$ levels (Figure 1).

Studies have shown that the use of triazines and ureas can induce oxidative stress (Bowler et al. 1992, Ivanov et al. 2005). Although bentazon does not belong to these classes of herbicides, it also acts by blocking the electron transport in photosynthesis, what originates reactive oxygen species, such as $\mathrm{H}_{2} \mathrm{O}_{2}$.

The increase of $\mathrm{H}_{2} \mathrm{O}_{2}$ content observed for bentazon in the first evaluation time possibly contributed to the higher values of thiobarbituric acid reactive species detected for the same herbicide at 12 and $24 \mathrm{HAA}$, if compared to the control (Figure 2). The same occurred with penoxsulam at 96 HAA. The reactive oxygen species can react with lipids, proteins and pigments, causing lipid peroxidation and membrane damage (Gill \& Tuteja 2010). Malondialdehyde is the product of lipid peroxidation, therefore, the highest content of this compound indicates oxidative stress (Han \& Wang 2002).

Han \& Wang (2002) also showed an increase in the level of malondialdehyde in rice plants after

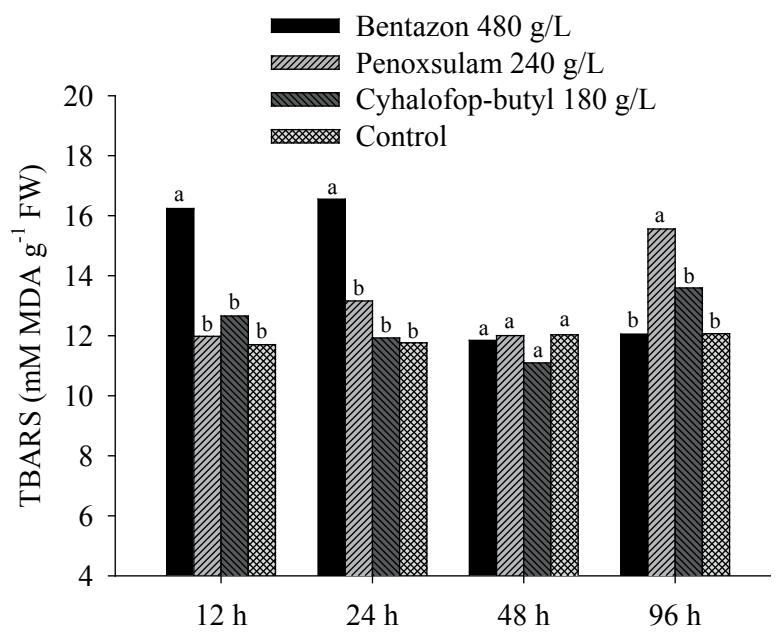

Figure 2. Content of thiobarbituric acid reactive species (TBARS) of rice plants in response to the use of bentazon (960 $\left.\mathrm{g} \mathrm{ha}^{-1}\right)$, penoxsulam (60 $\left.\mathrm{g} \mathrm{ha}^{-1}\right)$, cyhalofop-butyl $\left(315 \mathrm{~g} \mathrm{ha}^{-1}\right)$ and control, at 12, 24, 48 and 96 hours after application (Capão do Leão, Rio Grande do Sul State, Brazil, 2011/2012). Means followed by the same letter on the bars do not differ within each evaluation time by the Tukey test $(\mathrm{p}<0.05)$. applying $98.8 \mathrm{mM}$ of bentazon, suggesting that lipid peroxidation arises from the generation of reactive oxygen species, as a result of the interruption of electron transport in photosystem II (Han \& Wang 2002). However, the same authors demonstrated that the physiological response of plants depends on genotype, as the Tainung 67 cultivar kept low MDA levels after bentazon application.

Cyhalofop-butyl did not differ from the control, in terms of $\mathrm{H}_{2} \mathrm{O}_{2}$ and TBARS, in all evaluated time points (Figures 1 and 2). Therefore, the use of this ACCase inhibitor did not seem to generate oxidative stress in rice plants. Studies demonstrate that the fluazifop-P-butyl herbicide, belonging to the same group of cyhalofop-butyl, can cause lipid peroxidation in grasses (Luo et al. 2004). However, rice characteristics such as lack of esterase functionality, reduced absorption through the cuticle and increase in herbicide metabolism may help to explain the selectivity of rice after the application of cyhalofop-butyl (Ruiz-Santaella et al. 2006).

For enzyme activities, it was observed that the highest SOD activity was detected at 24 HAA of bentazon (11.9 $\mathrm{AU} \mathrm{mg} \mathrm{m}^{-1}$ protein $\mathrm{min}^{-1}$ ) and at 48 and 96 HAA of penoxsulam (11.3 and $12.4 \mathrm{AU} \mathrm{mg}^{-1}$ protein min $^{-1}$, respectively), when compared to the control (Figure 3).

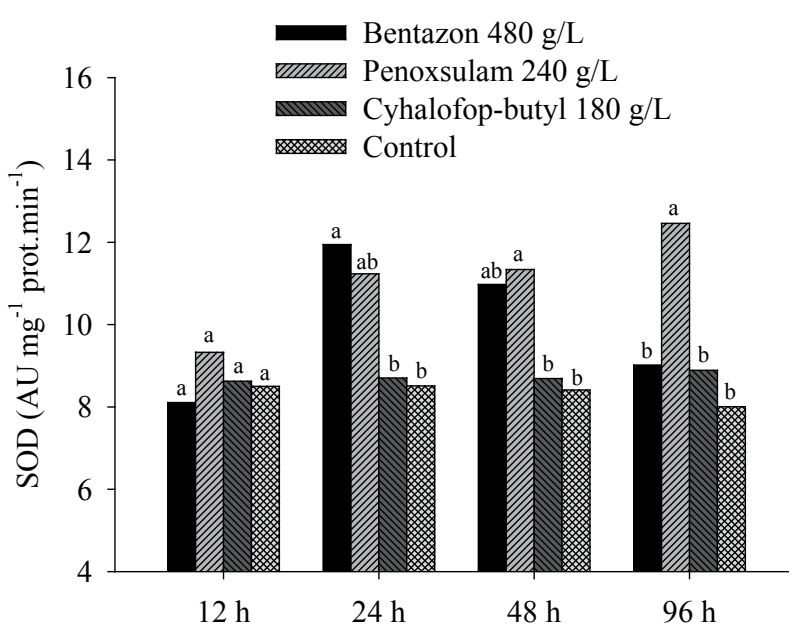

Figure 3. Superoxide dismutase activity (SOD) of rice plants in response to the use of bentazon (960 $\left.\mathrm{g} \mathrm{ha}^{-1}\right)$, penoxsulam (60 $\left.\mathrm{g} \mathrm{ha}^{-1}\right)$, cyhalofop-butyl (315 $\left.\mathrm{g} \mathrm{ha}^{-1}\right)$ and control, at 12, 24, 48 and 96 hours after application (Capão do Leão, Rio Grande do Sul State, Brazil, 2011/2012). Means followed by the same letter on the bars do not differ within each evaluation time by the Tukey test $(\mathrm{p}<0.05)$. 
The highest SOD activity in plants has been correlated with tolerance to oxidative stress (Iannelli et al. 1999). This protein belongs to the metalloenzymes that protect cells from superoxide radicals by catalyzing the dismutation of $\mathrm{O}_{2}^{--}$in $\mathrm{O}_{2}$ and $\mathrm{H}_{2} \mathrm{O}_{2}$. There are reports that plants treated with paraquat (Ekmekci \& Terzioglu 2005), fluroxypyr (Wu et al. 2010) and atrazine (Zhang et al. 2014) also showed an increase in the SOD activity, what may be linked to an increase in the superoxide radical formation, as well as to increases in gene and protein expression (Verma \& Dubey 2003) by superoxide-mediated signal transduction (Fatima \& Ahamad 2005).

The effects of bentazon on the antioxidant activity seem to be more evident in the first few hours after application. A research monitored the SOD gene expression at 1,2, 4 and 8 HAA of bentazon, in soybean plants, and showed the highest activity of SOD after 4 HAA (Zhu et al. 2009).

Corroborating our results, a lower activity of SOD was also observed in maize leaves after the application of clethodim (Radwan 2012). Clethodim acts like cyhalofop-butyl, i.e., inhibiting acetyl coenzyme-A carboxylase (ACCase). On the other hand, the herbicide haloxyfop-methyl, also an ACCase inhibitor, increased the SOD activity at 48 HAA in wheat plants (Janicka et al. 2008). The explanation for this variability remains unknown, but it can be hypothesized that the response against herbicides depends on several factors, such as species, active ingredient, concentration, environmental conditions, evaluation period, tissue and age of the plant, as well as enzyme isoforms.

For the CAT, it was observed that the treatment with bentazon showed a lower activity (0.53 AU $\mathrm{mg}^{-1}$ protein $\mathrm{min}^{-1}$ ) at $24 \mathrm{HAA}$, when compared to the control (Figure 4). For penoxsulam, it was also observed a lower CAT activity, if compared to the control at 48 and $96 \mathrm{HAA}\left(0.54\right.$ and $0.52 \mathrm{AU} \mathrm{mg}^{-1}$ protein $\mathrm{min}^{-1}$, respectively). Possibly, the reduction of CAT activity is due to the inhibition of the enzyme synthesis or change in the assembly of enzyme subunits under stress conditions caused by bentazon and penoxsulam (Abedi \& Pakniyat 2010). These results may be related to the greater presence of $\mathrm{H}_{2} \mathrm{O}_{2}$ detected after the application of these herbicides (Figure 1).

CAT has less affinity for $\mathrm{H}_{2} \mathrm{O}_{2}$ and, under environmental stresses, such as saline condition and high temperature, it can be inactivated, with subsequent degradation (Hertwig et al. 1992). Both SOD and CAT enzymes are almost restricted to the peroxisomes, which essentially work to remove $\mathrm{H}_{2} \mathrm{O}_{2}$, during photorespiration. This compartmentalization limits their ability to keep low the reactive oxygen species levels in other cellular compartments, such as chloroplast (Asada 2006).

Our results indicate that bentazon and penoxsulam induce significant changes in the physiological components evaluated, therefore indicating greater potential of these herbicides to cause oxidative stress in rice, when compared to cyhalofop-butyl. To mitigate the effects of these herbicides, the plant will enable the defense system, highlighting the role of the SOD and CAT enzymes.

In practical terms, considering only the effects on oxidation stress and antioxidant enzymes, cyhalofop-butyl (315 $\left.\mathrm{g} \mathrm{ha}^{-1}\right)$ has a lower potential to cause oxidative stress in rice crop. However, it is noteworthy that this herbicide is recommended only for the control of grasses (Agrofit 2014). If the area is infested by magnoliopsides and sedges, bentazon should be indicated. Initially, bentazon causes oxidative stress (up to 48 HAA), but the crop recovers the negative condition afterwards.

Further studies are needed also to investigate the effects of herbicides on shoot dry weight and crop

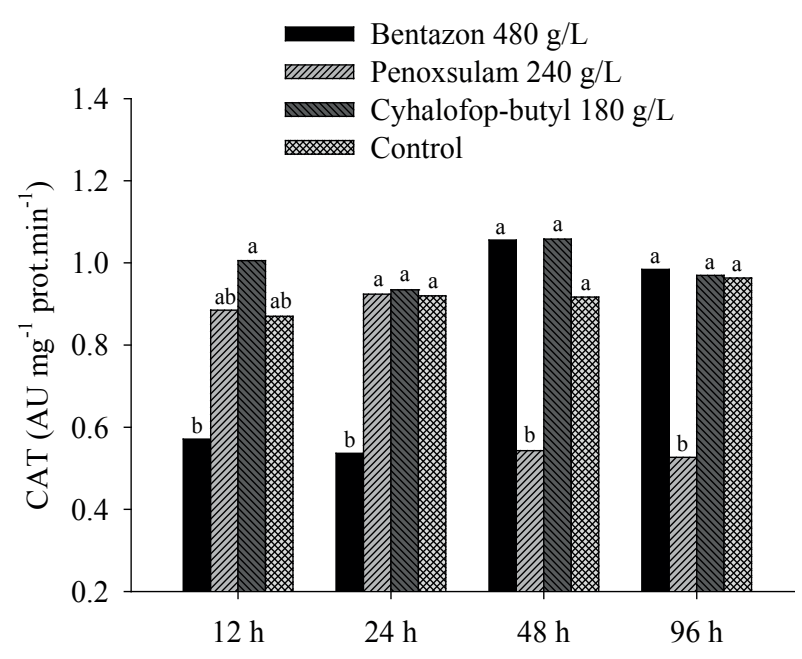

Figure 4. Catalase activity (CAT) of rice plants in response to the use of bentazon (960 $\left.\mathrm{g} \mathrm{ha}^{-1}\right)$, penoxsulam $\left(60 \mathrm{~g} \mathrm{ha}^{-1}\right)$, cyhalofop-butyl (315 $\mathrm{g} \mathrm{ha}^{-1}$ ) and control, at 12, 24, 48 and 96 hours after application (Capão do Leão, Rio Grande do Sul State, Brazil, 2011/2012). Means followed by the same letter on the bars do not differ within each evaluation time by the Tukey test $(p<0.05)$. 
yield components, such as the number of panicles and number of grains per panicle, since this understanding provides essential bases for a correct choice of herbicides used in weed control.

\section{CONCLUSIONS}

1. Bentazon (up to 24 hours after application) and penoxsulam (48 and 96 hours after application) reduce the catalase activity. Moreover, these herbicides increase $\mathrm{H}_{2} \mathrm{O}_{2}$, lipid peroxidation and superoxide dismutase activity, indicating a condition of oxidative stress in rice.

2. Cyhalofop-butyl do not alter the antioxidant activity, indicating that it causes less stress in rice crop.

\section{ACKNOWLEDGMENTS}

Authors gratefully acknowledge the financial support from DECIT/SCTIE-MS, through the Conselho Nacional de Desenvolvimento Científico e Tecnológico $(\mathrm{CNPq})$ and Fundação de Amparo à Pesquisa do Estado do Rio Grande do Sul (FAPERGS).

\section{REFERENCES}

ABEDI, T.; PAKNIYAT, H. Antioxidant enzyme changes in response to drought stress in ten cultivars of oilseed rape (Brassica napus L.). Czech Journal of Genetics and Plant Breeding, Slezská, v. 46, n. 1, p. 27-34, 2010.

AGROFIT. Sistema de agrotóxicos fitossanitários. 2014. Available at: <http://extranet.agricultura.gov.br/agrofit_ cons/principal_agrofit_cons $>$. Access: Jan. 19th, 2014.

ASADA, K. Production and scavenging of reactive oxygen species in chloroplasts and their functions. Plant Physiology, Rockville, v. 141, n. 2, p. 391-396, 2006.

BOWLER, C.; VAN MONTAGU, M.; INZÉ, D. Superoxide dismutase and stress tolerance. Annual Review of Plant Physiology and Plant Molecular Biology, Palo Alto, v. 43, n. 2, p. 83-116, 1992.

BRADFORD, M. M. A rapid and sensitive method for the quantitation of microgram quantities of protein utilizing the principle of protein-dye binding. Analytical Biochemistry, New York, v. 72, n. 7, p. 248-254, 1976.

EKMEKCI, Y.; TERZIOGLU, S. Effects of oxidative stress induced by paraquat on wild and cultivated wheats. Pesticide Biochemistry and Physiology, San Diego, v. 83, n. 2-3, p. 69-81, 2005.
FATIMA, R. A.; AHMAD, M. Certain antioxidant enzymes of Allium cepa as biomarkers for the detection of toxic heavy metals in wastewater. Science of the Total Environment, Amsterdam, v. 346, n. 1-3, p. 256-273, 2005.

FLECK, N. G.; VIDAL, R. A. Herbicidas inibidores do fotossistema 2. In: VIDAL, R. A.; MEROTTO JÚNIOR, A. (Eds.). Herbicidologia. Porto Alegre: Evangraf, 2001. p. $100-112$.

GILL, S. S.; TUTEJA, N. Reactive oxygen species and antioxidant machinery in abiotic stress tolerance in crop plants. Plant Physiology and Biochemistry, Paris, v. 48, n. 12, p. 909-930, 2010.

HAN, Y. C.; WANG, C. Y. Physiological basis of bentazon tolerance in rice (Oryza sativa L.) lines. Weed Biology and Management, Kyoto, v. 2, n. 4, p. 186-193, 2002.

HEATH, R. L.; PACKER, L. Photoperoxidation in isolated chloroplasts: I. Kinetics and stoichiometry of fatty acid peroxidation. Archives of Biochemistry and Biophysics, New York, v. 125, n. 1, p. 189-198, 1968.

HERTWIG, B.; STREB, P.; FEIERABEND, J. Light dependency of catalase synthesis and degradation in leaves and the influence of interfering stress conditions. Plant Physiology, Rockville, v. 100, n. 3, p. 1547-1553, 1992.

HESS, F. D. Light-dependent herbicides: an overview. Weed Science, Champaign, v. 48, n. 2, p. 160-170, 2000.

IANNELLI, M. A. et al. Tolerance to low temperature and paraquat mediated oxidative stress in two maize genotypes. Journal of Experimental Botany, Eynsham, v. 50, n. 333, p. 523-532, 1999.

IVANOV, S. V.; ALEKSIEVA, V. S.; KARANOV, E. N. Cumulative effect of low and high atrazine concentrations on Arabidopsis thaliana plants. Russian Journal of Plant Physiology, Moscow, v. 52, n. 2, p. 213-219, 2005.

JANICKA, U. et al. The effect of haloxyfop-ethoxyethyl on antioxidant enzyme activities and growth of wheat leaves (Triticum vulgare L.). Polish Journal of Environmental Studies, Olsztyn, v. 17, n. 4, p. 485-490, 2008.

KRUSE, N. D. et al. Estresse oxidativo em girassol (Helianthus annuus) indica sinergismo para a mistura dos herbicidas metribuzin e clomazone. Planta Daninha, Viçosa, v. 24, n. 2, p. 379-390, 2006.

LUO, X. Y.; SUNOHARA, Y.; MATSUMOTO, H. Fluazifop-butyl causes membrane peroxidation in the herbicide-susceptible broad leaf weed bristly starbur (Acanthospermum hispidum). Pesticide Biochemistry and Physiology, San Diego, v. 78, n. 2, p. 93-102, 2004.

MA, N. L.; RAHMAT, Z.; LAM, S. S. A review of the "omics" approach to biomarkers of oxidative stress in Oryza sativa. International Journal of Molecular Sciences, Basel, v. 14, n. 4, p. 7515-7541, 2013. 
OLIVEIRA JÚNIOR, R. S.; CONSTANTIN, J.; INOUE, M. H. (Eds.). Biologia e manejo de plantas daninhas. Curitiba: Omnipax, 2011.

PEIXOTO, P. H. P. Aluminum effects on lipid peroxidation and on the activities of enzymes of oxidative metabolism in sorghum. Revista Brasileira de Fisiologia Vegetal, Brasília, DF, v. 11, n. 3, p. 137-143, 1999.

RADWAN, D. E. M. Salicylic acid induced alleviation of oxidative stress caused by clethodim in maize (Zea mays L.) leaves. Pesticide Biochemistry and Physiology, San Diego, v. 102, n. 2, p. 182-188, 2012.

RUIZ-SANTAELLA, J. P.; HEREDIA, A.; PRADO, R. D. Basis of selectivity of cyhalofop-butyl in Oryza sativa L. Planta, Berlin, v. 223, n. 2, p. 191-199, 2006.

SENSEMAN, S. A. Herbicide handbook. 9. ed. Lawrence: Weed Science Society of America, 2007.

SERGIER, I.; ALEXIEVA, V.; KARANOV, E. Effect of spermine, atrazine and combination between them on some endogenous protective systems and stress markers in plant. Comptes Rendus de l'Académie Bulgare des Sciences, Sofia, v. 51, n. 3, p. 121-124, 1997.
SONG, N. H. et al. Biological responses of wheat (Triticum aestivum) plants to the herbicide chlorotoluron in soils. Chemosphere, Oxford, v. 68, n. 9, p. 1779-1787, 2007.

SUDHAKAR, C.; LAKSHMI, A.; GIRIDARAKUMAR, S. Changes in the antioxidant enzyme efficacy in two high yielding genotypes of mulberry (Morus alba L.) under $\mathrm{NaCl}$ salinity. Plant Science, Ottawa, v. 161, n. 3, p. 613-619, 2001.

VERMA, S.; DUBEY, R. S. Lead toxicity induces lipid peroxidation and alters the activities of antioxidant enzymes in growing rice plants. Plant Science, Ottawa, v. 164, n. 4, p. 645-655, 2003.

WU, G. L. et al. Fluroxypyr triggers oxidative damage by producing superoxide and hydrogen peroxide in rice (Oryza sativa). Ecotoxicology, London, v. 19, n. 1, p. 124132, 2010.

ZHANG, J. J. et al. Accumulation and toxicological response of atrazine in rice crops. Ecotoxicology and Environmental Safety, New York, v. 102, n. 2, p. 105112, 2014.

ZHU, J. et al. Effects of photosystem-II-interfering herbicides atrazine and bentazon on the soybean transcriptome. The Plant Genome, Madison, v. 2, n. 2, p. 191-205, 2009. 